\title{
HUBUNGAN ANTARA LAMA KETUBAN PECAH DINI ATERM DENGAN KEJADIAN INFEKSI PADA NEONATUS PERIODE 1 JANUARI S/D 31 DESEMBER 2010 DI RSU PROVINSI NTB
}

\author{
Ida Ayu Made Mahayani \\ Fakultas Kedokteran Universitas Islam Al-Azhar \\ Jl. Unizar No.20 Turida Mataram \\ Email : Gexmahayani@gmail.com
}

\begin{abstract}
ABSTRAK
Ketuban pecah dini adalah pecahnya selaput ketuban pada sembarang waktu. Ketuban pecah dini merupakan salah satu faktor penyebab terjadinya infeksi dan asfiksia. Penelitian ini bertujuan untuk mengetahui apakah ada hubungan antara lama ketuban pecah dini aterm dengan kejadian infeksi pada neonatus periode 1 januari s/d 31 desember 2010 di RSU Provinsi NTB. Metode yang digunakan adalah analitik dengan pendekatan case control study dengan tehnik pengambilan data sistematik random sampling untuk kelompok control dan total populasi untuk kelompok kasus. Pada penelitian ini sampel yang digunakan sebanyak 155 sampel yang memenuhi kreteria inklusi dan eksklusi. Hasil penelitian didapatkan bahwa responden dengan ketuban pecah dini aterm yang $\geq 12$ jam mengalami infeksi neonatus sebesar 31 kasus $(50,8 \%)$ dan tidak mengalami infeksi sebesar 30 kasus $(49,2 \%)$. Sedangkan ketuban pecah dini aterm yang < 12 jam yang mengalami infeksi sebesar 26 kasus $(27,7 \%)$ dan yang tidak mengalami infeksi sebesar 68 kasus $(72,3 \%)$. Uji statistik menggunakan Chi-square didapatkan hasil $P$ value sebesar 0,003 dengan alpha $0,05(\alpha=5 \%)$ dan uji statistik menggunakan Coefisien Contingency didapatkan $P$ value sebesar 0,003 dengan alpha 0,05 $(\alpha=5 \%)$ maka terdapat Hubungan Antara Lama Ketuban Pecah Dini Aterm dengan Kejadian Infeksi Pada Neonatus Periode 1 Januari s/d 31 Desember 2010 di RSU Provinsi NTB.
\end{abstract}

Kata Kunci : Ketuban Pecah Dini, Infeksi Neonatus.

\section{PENDAHULUAN}

Ukuran keberhasilan suatu pelayanan kesehatan tercermin dari penurunan angka kematian ibu dan bayi sampai pada batas angka terendah yang dapat dicapai sesuai dengan kondisi, situasi setempat, dan waktu. Berdasarkan Survei Demografi dan Kesehatan Indonesia (SDKI) 2002/2003, angka kematian ibu (AKI) di Indonesia masih berada pada angka 307 per 100.000 kelahiran hidup atau setiap jam terdapat 2 orang ibu bersalin meninggal karena berbagai sebab (Depkes RI, 2007). Sedangkan angka kematian bayi 52 per 1000 kelahiran hidup dan angka kematian neonatal 25 per 1000 kelahiran hidup (Fithria, 2009).

Masa neonatus merupakan waktu yang sangat rentan pada bayi, yang sedang menyempurnakan penyesuaian fisiologis yang diperlukan untuk kehidupan di ekstra uterin. Infeksi pada neonatus merupakan sebab yang penting terhadap terjadinya morbiditas dan mortalitas selama periode ini. Lebih kurang $2 \%$ janin dapat terinfeksi in utero dan $10 \%$ bayi baru lahir terinfeksi selama persalinan atau dalam bulan pertama kehidupan (Bherman, 1996). Berdasarkan perkiraan World Health Organitation (WHO) Lebih dari dua pertiga 
kematian itu terjadi pada periode neonatal dini dan $42 \%$ kematian neonatal disebabkan infeksi seperti: sepsis, tetanus neonatorum, meningitis, pneumonia, dan diare (Simaremare, 2010).

Laporan WHO tahun 2005 angka kematian bayi baru lahir di Indonesia adalah 20 per 1000 kelahiran hidup. Indonesia sekitar 5 juta per tahun dan angka kematian bayi 20 per 1000 kelahiran hidup, berarti sama halnya dengan setiap hari 246 bayi meninggal. Menurut laporan Dinas Kesehatan Provinsi Nusa Tenggara Barat tahun 2009, kematian neonatus di NTB salah satunya disebabkan oleh infeksi yaitu sebesar 4,49\% dari seluruh penyebab kematian pada neonates.

Ketuban pecah dini disebabkan oleh karena berkurangnya kekuatan membran atau meningkatnya tekanan intrauterin akibat beberapa faktor. Dimana insiden ketuban pecah dini berkisar 8-10\% dari semua kehamilan, lebih banyak terjadi pada kehamilan cukup bulan dibandingkan dengan kurang bulan yaitu sekitar 95\% terjadi pada kehamilan cukup bulan (Yance Michael,1996) sedangkan menurut Smith Joseph (2001) 35\% terjadi pada kehamilan kurang bulan atau preterm.

Berdasarkan Rekam Medis di Rumah Sakit Umum Provinsi NTB, dimana angka morbiditas ibu dengan ketuban pecah dini aterm mengalami peningkatan dalam tiga tahun terakhir ini. Dimana pada tahun 2010 mencapai angka insiden tertinggi yaitu $14,54 \%$ dari seluruh kehamilan yang ada. Sedangkan insiden infeksi neonatus pada tahun 2010 sebesar 3,34 \% dari seluruh penyebab morbiditas pada neonatus yang ada di Rumah Sakit Umum Provinsi NTB. Ketuban pecah dini merupakan salah satu faktor resiko terjadinya infeksi pada ibu maupun pada neonatus yang sangat besar dan potensiil. Berdasarkan latar belakang tersebut maka peneliti ingin meneliti “ Hubungan Antara Lama Ketuban Pecah Dini Aterm dengan Kejadian Infeksi Pada Neonatus Di RSU Provinsi NTB Periode 1 Januari 2010 s/d 31 Desember 2010 “

\section{METODELOGI PENELITIAN}

Penelitian ini menggunakan metode penelitian analitik observasional dengan pendekatan case control study. Dalam penelitian ini teknik pengambilan sampel menggunakan sistematik random sampling.

\section{Pengambilan Sampel}

Populasi adalah keseluruhan objek penelitian/objek yang diteliti (Notoatmodjo, 2010). Populasi pada penelitian ini adalah semua neonatus dengan status ibu ketuban pecah dini di Rumah Sakit Umum Provinsi NTB periode 1 Januari s/d 31 Desember 2010.

Kreteria inklusi dari penelitian ini : 
Ibu hamil aterm dengan ketuban pecah dini, Persalinan berlangsung spontan tanpa tindakan ( forcep, vacuum ekstraksi, seksio

HASIL DAN PEMBAHASAN

Karakteristik Penelitian Status Lama

Ketuban Pecah Dini Aterm Responden sesaria ), dan Ibu hamil tidak menderita penyakit penyerta lainnya.

\begin{tabular}{|c|c|c|}
\hline $\begin{array}{l}\text { Ketuban Pecah } \\
\text { Dini }\end{array}$ & Frekuensi (f) & Persentase $(\%)$ \\
\hline$\geq 12$ jam & 61 & 39,4 \\
\hline$<12$ jam & 94 & 60,6 \\
\hline TOTAL & 155 & 100 \\
\hline
\end{tabular}

Tabel 1.1. Distribusi Frekuensi Responden Berdasarkan lama ketuban pecah dini.

Tabel 2.1. Distribusi Frekuensi Responden Berdasarkan Neonatus Dengan Status Ibu Ketuban Pecah Dini Aterm.

\begin{tabular}{|l|c|c|}
\hline Satus Neonatus & Frekuensi (f) & Persentase (\%) \\
\hline Infeksi Neonatus & 57 & 36,8 \\
\hline Non Infeksi Neonatus & 98 & 63,2 \\
\hline \multicolumn{1}{|c|}{ TOTAL } & 155 & 100 \\
\hline
\end{tabular}

Distribusi Lama Ketuban Pecah Dini

Aterm Dengan Infeksi Pada Neonatus

Tabel 3.1. Tabel Silang lama ketuban pecah dini aterm dengan infeksi pada Neonatus

\begin{tabular}{|c|c|c|c|}
\hline \multirow{2}{*}{$\begin{array}{c}\text { Lama ketuban } \\
\text { Pecah Dini } \\
\text { Aterm }\end{array}$} & \multicolumn{2}{|c|}{ Infeksi Neonatus } & \multirow{2}{*}{ TOTAL } \\
\cline { 2 - 4 } & Infeksi & Non Infeksi & \\
\hline$\geq 12$ jam & $31(50,8 \%)$ & $30(49,8 \%)$ & $\mathbf{6 1}(\mathbf{1 0 0 \%})$ \\
\hline$<12$ jam & $26(27,7 \%)$ & $68(72,3 \%)$ & $\mathbf{9 4}(\mathbf{1 0 0 \%})$ \\
\hline Total & $\mathbf{5 7 ( 5 0 \% )}$ & $\mathbf{9 8 ( 6 3 , 2 \% )}$ & $\mathbf{1 5 5 ( 1 0 0 \% )}$ \\
\hline
\end{tabular}


Tabel 4.1. Tabel Silang lama ketuban pecah dini aterm dengan infeksi pada neonatus

\begin{tabular}{lccc}
\hline Ketuban Pecah Dini Aterm & \multicolumn{2}{c}{ Infeksi Pada Neonatus } & \multirow{2}{*}{ TOTAL } \\
\cline { 2 - 3 } & Infeksi & Non Infeksi & \\
\hline$\geq 12$ jam & 31 & 30 & 58 \\
\hline$<12$ jam & 26 & 68 & 97 \\
\hline TOTAL & 57 & 98 & 155 \\
\hline
\end{tabular}

Sumber : Data primer yang diolah

$$
\begin{aligned}
& \mathrm{OR}=\mathrm{AD} / \mathrm{BC} \\
& \mathrm{OR}=\frac{31 \times 68}{26 \times 30} \\
& \mathrm{OR}=\frac{2108}{780} \\
& \mathrm{OR}=2,70 \\
& \mathrm{OR}=3
\end{aligned}
$$

Berdasarkan Tabel 3.1 dapat diketahui dari 155 sampel didapatkan bahwa responden dengan ketuban pecah dini aterm yang $\geq 12$ jam mengalami infeksi neonatus sebesar 31 kasus $(50,8 \%)$ dan tidak mengalami infeksi sebesar 30 kasus $(49,2 \%)$. Sedangkan ketuban pecah dini aterm yang $<12$ jam yang mengalami infeksi neonatus sebesar 26 kasus $(27,7 \%)$ dan yang tidak mengalami infeksi sebesar 68 kasus $(72,3 \%)$.

Untuk mengetahui hubungan lama ketuban pecah dini aterm dengan infeksi neonatus, maka digunakan uji korelasi Contingency Coefficient. Namun, sebelum melakukan uji korelasi Contingency
Coefficient, peneliti melakukan uji ChiSquare untuk mengetahui perbedaan infeksi neonatus pada ibu yang mengalami KPD $\geq$ 12 jam dan $<12$ jam. Berdasarkan uji Chisquare hasil analisis Chi-square pada table di atas diperoleh nilai signifikansi atau $P$ value sebesar 0,003 yang lebih kecil dari alpha $0,05(\alpha=5 \%)$, sehingga Ho ditolak dan hasil uji Kontingen Contingency $(C)$ pada tabel 4.5 diperoleh nilai signifikansi atau $P$ value sebesar 0,003 yang lebih kecil dari alpha $0,05 \quad(\alpha=5 \%)$, sehingga Ho ditolak dan dapat disimpulkan bahwa ada hubungan antara lama ketuban pecah dini aterm dengan kejadian infeksi pada neonatus, dengan risiko kesalahan dibawah $5 \%(\mathrm{p}<0.05)$, yang menunjukkan tingkat akurasi yang cukup tinggi untuk menolak Ho.

Dari hasil tersebut kebanyakan responden dengan ketuban pecah dini aterm $\geq 12$ jam mengalami infeksi dibandingkan dengan responden yang mengalami ketuban 
pecah dini aterm $<12$ jam dan sebaliknya. Ini Sesuai dengan teori yang dikemukakan oleh Hasan dan Alatas (2007) ketuban pecah lama adalah jarak waktu antara pecahnya ketuban dan lahirnya bayi lebih dari 12 jam yang mempunyai peranan penting terhadap timbulnya plasentitis dan amnionitis. Dimana ketuban pecah dini merupakan masalah penting dalam obstetrik berkaitan dengan penyulit kelahiran prematur dan terjadinya infeksi khorioamnionitis sampai sepsis yang meningkatkan mortalitas dan morbiditas perinatal (Prawirohardjo, 2007).

Namun dari data diatas juga didapatkan bahwa ketuban pecah dini aterm < 12 jam ada mengalami infeksi dan ketuban pecah dini aterm $\geq 12$ jam ada yang tidak mengalami infeksi, hal ini dapat saja terjadi akibat pengelolaan ibu dengan ketuban pecah dini dan penanganan neonatus saat persalinan serta perawatan yang tidak optimal dapat meningkatkan risiko terjadinya morbiditas pada ibu dan bayi dan sebaliknya (Anonim, 2002).

Dari Tabel 4.1 didapatkan perhitungan Odds Rasio di atas diperoleh hasil Odds Rasio (OR) sebesar 3 (OR > 1), hal ini menunjukkan bahwa variabel independent tersebut merupakan faktor risiko yang mempengaruhi varibel dependen yang dalam hal ini didapatkan bahwa lama ketuban pecah dini aterm yang $\geq 12$ jam merupakan fakto risiko untuk mempengaruhi terjadinya infeksi pada neonatus sebesar 3 kali lipat.

Dari hasil uji berbagai data diatas, sesuai dengan teori yang dikemukakan oleh Ketut Suwiyoga, AA Raka Budayasa (2007) mengatakan bahwa antara ketuban pecah dini dengan terjadinya infeksi pada ibu dan bayi keduanya saling mempengaruhi. Lebih lanjut dijelaskan bahwa ketuban pecah dini dapat memudahkan infeksi ascenden. Infeksi ini dapat berupa amnionitis dan korionitis atau gabungan keduanya disebut korioamnionitis. Selain itu korioamnionitis dapat dihubungkan dengan lama pecah selaput ketuban. Semakin lama periode laten, semakin lama pula kala satu persalinan dan semakin besar insidensi infeksi. Janin bisa terinfeksi sekalipun tidak terlihat tanda-tanda sepsis pada ibu. Tempat paling sering mengalami infeksi adalah traktus respiratorius (Oxorn, 2003; Wiknjosastro, 2007).

Penelitian retrospektif menggunakan case control study yang dilakukan Dian Puji (2010) di RS. HS. Samsoeri Mertojoso Surabaya didapatkan hasil bahwa yang masing-masing 63 (50\%) mengalami ketuban pecah dini dan tidak mengalami ketuban pecah dini. Sebagian besar 100 (79\%) bayi mengalami infeksi neonatus dan $26(21 \%)$ tidak mengalami infeksi 
neonatus. Terdapat hubungan antara ketuban pecah dini dengan kejadian infeksi neonatus.

Suwiyoga dan Budayasa (2007) dalam penelitiannya di rumah sakit Sanglah Denpasar menemukan Risiko relatif infeksi dengan sepsis neonatorum dini pada lama ketuban pecah 12-18 jam adalah 6 kali $(\mathrm{RR}=6,21$ ci $95 \%$ 1,89-33,09) dan pada 18 24 jam adalah 9 kali $(\mathrm{RR}=9,29$ ci $95 \%$ 1,08-80,12) lebih besar dibandingkan dengan ketuban pecah dini kurang dari 12 jam. Insidensi sepsis pada ibu dengan lama ketuban pecah kurang 12 jam adalah 2,7\% dibandingkan $5,2 \%$ pada subjek dengan lama ketuban pecah lebih 12 jam, kasus sepsis paling tinggi (4 kasus - 80\%) ditemukan pada persalinan setelah 18 jam pecah ketuban. Insidens sepsis neonatorum pada persalinan setelah ketuban pecah 18 jam adalah 11,7 \% dibandingkan dengan 1,3\% pada persalinan kurang dari 18 jam setelah pecah ketuban.

\section{KESIMPULAN}

1. Dari hasil penelitian ibu dengan ketuban pecah dini yang $<12$ jam lebih banyak dibandingkan dengan ibu yang mengalami ketuban pecah dini $\geq 12$ jam yaitu sebesar 39,4\% sedangkan ibu dengan ketuban pecah dini $<12$ jam sebesar $60,9 \%$.
2. Dari hasil penelitian neonatus yang tidak mengalami infeksi lebih banyak dibandingan dengan yang mengalami infeksi yaitu sebesar $36,8 \%$ sedangkan yang mengalami infeksi sebesar $63,2 \%$.

3. Didapatkan $P$ value sebesar 0,003 yang menunjukkan bahwa terdapat hubungan antara lama ketuban pecah dini dengan kejadian infeksi pada neonatus periode 1 januari s/d 31 desember 2010 di Rumah Sakit Umum Provinsi NTB

4. Uji statistik menggunakan Chi-Square menunjukkan adanya perbedaan antara ketuban pecah dini yang $\geq 12$ jam berisiko lebih besar terjadinya infeksi pada neonatus dibandingkan dengan ibu yang mengalami ketuban pecah dini $<12$ jam .

5. Uji statistik menggunakan Koefisien Contingency menunjukkan ketuban pecah dini yang $\geq 12$ jam berisiko lebih besar terjadinya infeksi pada neonatus dibandingkan dengan ibu yang mengalami ketuban pecah dini $<12$ jam.

6. Dari hasil penghitungan Odds Ratio didapatkan bahwa $\mathrm{OR}=3(\mathrm{OR}>1)$, yang dalam hal ini berarti lama ketuban pecah dini merupakan faktor risiko yang dapat menyebabkan terjadinya infeksi pada neonatus, dimana ketuban pecah dini $\geq 12$ jam memiliki risiko 3 
kali lipat untuk mengalami infeksi pada neonatus.

\section{DAFTAR PUSTAKA}

Anonim.2002." Premature Rupture of Membrane ". http://www.mcevoy.demon.co.uk/me dicine/ObsGyn/Obstetric/labour/PRO M.html dikutip tanggal 27 Februari 2011.

Behrman RE, Kliegman R, Arvin AM.1996. Infeksi pada bayi baru lahir. Didalam Wahab S, editor. Ilmu kesehatan anak nelsson. Jakarta. EGC; hlm635-36

Cunningham, MacDonald, Gant. 1995. Obstetri Williams edisi 18. Jakarta : Penerbit Buku Kedokteran EGC.

Departeman Kesehatan RI.1996. Kedaruratan Kebidanan Buku Ajar Untuk Program Pendidikan Bidan, Jakarta : Penerbit Departemen Kesehatan.

Departeman Kesehatan RI. 2007. Kedaruratan Kebidanan Buku Ajar Untuk Program Pendidikan Bidan, Jakarta : Penerbit Departemen Kesehatan.

Dinas Kesehatan Nusa Tenggara Barat. 2009. Laporan Tahunan Seksi Kesehatan Ibu dan Anak Bidang Bina Kesehatan Masyarakat, NTB : Dinas Kesehatan NTB.

Fithria. 2009. Konsep kehamilan. http://fithria2207.wordpress.com/ dikutip tanggal 27 Februari 2011.

Hassan,R, Alatas, H. 1985. Buku Kuliah Ilmu Kesehatan Anak, Jilid 3, Jakarta : Balai Penerbit FKUI.

Hacker Neville.F., Moor J.George.2001. Ketuban Pecah Dini dalam Esensial Obstetri dan Ginekologi edisi 2, Hipokrates. Jakarta, hal : 304 - 306
Hakimi,M. 2003. Fisiologi dan Patologi Persalinan ( terjemahan ). Jakarta : Yayasan Essensia Medica.

Herasari, Dian Puji.2010. Habungan Antara Ketuban Pecah Dini dengan Kejadian Infeksi Pada Neonatus Usia 0-7 hari di RS. HS. Samsoeri Mertojoso Surabaya. http://www.fk.unair.ac.id/attachment s/1596_Diana Puji Herasari.pd. dikutip tanggal 10 Mei 2011.

Manuaba, I.B.G.,1993.Penuntun Kepaniteraan Klinik Obstetri dan Ginekologi,Jakarta : Penerbit Buku Kedokteran EGC.

Manuaba, I.B.G. 1998. Ilmu kebidanan, Penyakit Kandungan, dan KeluargaBerencana, Jakarta : Penerbit Buku Kedokteran EGC.

Midwifery, V.2004. Ilmu Kebidanan, Bandung : Penerbit Sekeola Publisher.

Mocthar, R.1998. Sinopsis Obstetri I, Jakarta : Penerbit Buku Kedokteran EGC.

Phupong Vorapong.2003. Prelabour Rupture of Memnranes in Journal of Pediatric Obstetric and Gynaecology, Nov/Dec, Hal : 25 - 31.

Prawirahardjo, S. 2007. Ilmu Kebidanan, Jakarta : Penerbit Yayasan Bina Pustaka.

Prawirahardjo, S.2002. Ilmu Kebidanan, Jakarta : Penerbit Yayasan Bina Pustaka.

Prawirahardjo, S.. 2007. Pelayanan Kesehatan Maternal dan Neonatal. Jakarta :Penerbit Yayasan Bina Pustaka.

Pratiknyo, A.W.1993. Dasar-Dasar Metodologi Penelitian Kedokteran dan Kesehatan. Penerbit CV. Jakarta: Rajawali. 
Sastroasmoro, sudigdo. 1995.Dasar-Dasar Metodologi Penelitian Klinis. Jakarta: Binarupa Aksara.

Suharsimi Arikunto, 1998. Metodologi Penelitian, Jakarta: Reineka Cipta.

Suwiyoga, S., Budayasa, R.AA., 2002. Peran Korioamnionitis Klinik, Lama Ketuban Pecah, dan Jumlah Periksa Dalam pada Ketuban Pecah Dini Kehamilan Aterm terhadap Insiden Sepsis Neonatorum Dini. http://www.kalbe.co.id/files/cdk/files /158_07Perankorioamnionitisklinikk etubanpecah.pdf/158_07Perankorioa mnionitisklinikketubanpecah.html dikutip tanggal 11 Mei 201.

Suwiyoga, S., Budayasa, R.AA., 2007. Peran Korioamnionitis Klinik, Lama Ketuban Pecah, dan Jumlah Periksa Dalam pada Ketuban Pecah Dini Kehamilan Aterm terhadap Insiden Sepsis Neonatorum Dini. Cermin Dunia Kedokteran, 239-241.

Simaremare. 2010. Hubungan Antara Tingkat Pengetahuan Ibu dengan Kejadian Sepsis Neonaturum. http://repository.usu.ac.id/bitstream/1 23456789/16575/8/Chapter\%20I.pdf dikutip tanggal 26 Februari 2011.

Smith Joseph. 2001. Premature Ruptur Of Membranes.

http://.www.chclibary.019/microwed/ 0061770.htlm dikutip tanggal 27 Februari 2011.

Staf Pengajar FK UI. 2007. Ilmu Kesehatan Anak, cetakan ke 11. Jakarta : Fakultas Kedokteran UI.

Wiknjosastro H. 2007. Ilmu Kebidanan, cetakan ke 7. Jakarta : Yayasan Bina pustaka.

Yancey Michael.K.1999. Prelabor Rupture of Membrane at Term. http://www.medicaljournal.co.cc/2010/03/infeksi-nifas- dan-ketuban-pecah-dini.html dikutip tanggal 27 februari 2011. 